\title{
On the Typology of Inflection Class Systems
}

\author{
Wolfgang U. Dressler, Marianne Kilani-Schoch, Natalia \\ Gagarina, Lina Pestal, Markus Pöchtrager
}

\begin{abstract}
Inflectional classes are a property of the ideal inflecting-fusional language type. Thus strongly inflecting languages have the most complex vertical and horizontal stratification of hierarchical tree structures. Weakly inflecting languages which also approach the ideal isolating type or languages which also approach the agglutinating type have much shallower structures. Such properties follow from principles of Natural Morphology and from the distinction of the descendent hierarchy of macroclasses, classes, subclasses, subsubclasses etc. and homogeneous microclasses. The main languages of illustration are Latin, Lithuanian, Russian, German, French, Finnish, Hungarian and Turkish.
\end{abstract}

\section{Introduction}

The structure of inflection class systems is a major object of the third subtheory of Natural Morphology (henceforth NM), viz. the theory of language-specific system adequacy, as pioneered by Wurzel (1984; cf. Dressler 2002, KilaniSchoch \& Dressler 2005). In this frame-work inflection systems of the following languages have been dealt with: Bulgarian (Manova \& Dressler 2001), Croatian (Dressler, Dziubalska-Kołaczyk \& Katičić 1996), Finnish (Pöchtrager et al. 1998), French (Dressler \& Kilani-Schoch 2003, Kilani-Schoch \& Dressler 2005), German (Dressler 2003), Hungarian (Pöchtrager et al. 1998), Italian (Dressler \& Thornton 1996), Latin (Dressler 2002), Polish (Dressler \& Dziubalska-Kołaczyk 1997), Russian (Dressler \& Gagarina 1999), Spanish (Aguirre $\&$ Dressler, this volume). In this contribution, we will go beyond such accounts of language-specific inflection-class systems and focus on their comparison from the perspective of the second subtheory of NM, viz. the theory of typological adequacy (Dressler 1985, Kilani-Schoch \& Dressler 2005). We will try to show the typological relevance of the respective concepts of NM. The languages analysed will be English, Finnish, French, German, Hungarian, Latin, Lithuanian, Russian and Turkish. In general, in other frame-works, inflection class systems are too vaguely described, not much preciser than Priscian's description of the traditional Latin inflection classes (cf. Dressler 2002), at least in respect of the 
hierarchy of classes, the differentiation of identical and similar patterning, and the distinction of regular, subregular and irregular paradigms.

Our account starts from the following definitions (as exposed in the above descriptions, cf. Kilani-Schoch \& Dressler 2005):

Sets of similar inflectional paradigms form inflectional classes (in the generic sense), in hierarchical order: macroclass, class (in the specific sense: similar to the traditional term of, e.g., the five Latin declension classes, where not all nouns of one class inflect in exactly the same way), subclass, (subsubclass, if necessary, etc.), microclass. All classes are defined by implicational paradigm structure conditions (cf. Wurzel 1984, Kilani-Schoch \& Dressler 2005).

An inflectional microclass is the smallest subset of an inflectional class above the paradigm, definable as the set of paradigms which share exactly the same morphological generalisations, but may differ via the application of phonological processes: phonological assimilation of voicedness in top- $s$ [tops] vs. dog-s [dogz] does not establish a different plural microclass, whereas morphonological assimilation in wive-s [waivz] does. A paradigm which differs at least in one property from any other paradigm, is an isolated paradigm: these are the only really irregular verbs or nouns (e.g. E. to have, child), whereas small unproductive, minor microclasses are subregular (e.g. E. to sing, goose).

An inflectional macroclass is the highest, most general type of class, which comprises several (sub-sub-)classes or, at least, microclasses. Prototypically, its nucleus is a productive microclass and it has at least two microclasses. The interior coherence of a macroclass, in terms of shared properties and paradigm structure conditions, must be higher than affinities between microclasses of different macroclasses.

The highest inflectional set below inflectional morphology as a whole and above macroclasses is a system of inflection, i.e. the set of all paradigms formed from bases belonging to the same word class, such as the system of verb inflection.

The hierarchical make-up of a macroclass follows the principle of default inheritance (cf. Corbett \& Fraser 1993) and can be represented by a tree structure, as for German verbs (cf. Dressler 2003) in tree 1.

\section{German Verb Inflection}

Macroclass I (weak verbs) comprises all verbs which have a t-preterit and t-past participle (similar to English and Dutch) and the default of no ablaut (apophony). This default is converted into an obligatory property in the first class, e.g. first microclass: spiel-en 'to play' - Pret. spiel-te - Past Part. ge-spiel-t, the default microclass, which is the only productive one. In class 2 (microclasses 3 to 5), e.g. microclass 3 (6 verbs), this default is overridden, as in brenn-en 'to burn' - brann-te - ge-brann-t. Macroclass II (strong verbs) has at least one 
ablaut form (1A: in the preterit), an n-past participle and no t-preterit (unless in transitional forms which are isolated paradigms, such as mahl-en 'to grind' - mahl-te-ge-mahl-en, more in Bittner 1996). Moreover macroclass II has the default of at least one umlaut (metaphony: 1U) in the present of its paradigm. Class III overrides this default, class I inherits it (with the exception of microclass 11), class II converts into just one obligatory umlaut (e.g. schlaf-en 'to sleep' - 3.Sg.Prs. schläf-t - schlief - ge-schlaf-en). Furthermore, class I adds a further umlaut form (in the imperative) and in its first subclass a further ablaut to the inherited properties.

\section{Inflecting-Fusional Type}

Inflectional class systems are typical for the inflecting-fusional language type. Here we define a language type as an ideal construct, to which inflection systems approach to a greater or smaller degree (according to the typological theory of Skalička 1978; 2002 and its adaptation to the theory of Natural Morphology - cf. Dressler 1985, Kilani-Schoch \& Dressler 2005). Thus the ideal inflecting-fusional type is approached by (especially conservative) Indo-European and Bantu languages, here represented to a large degree (in descending order) by Latin, Lithuanian and Russian. Languages which mix properties of the inflecting-fusional and the agglutinating or isolating type, have shallower and more restricted inflection class tree structures. Among our languages, generally, Hungarian is more agglutinating than Finnish, and French is, overall, more isolating than German.

These typological characteristics may not be equal for the inflection class systems of nouns and verbs within the same language. Thus the French noun system is much more isolating than its verb system (cf. Dressler \& Kilani-Schoch 2003, Dressler et al. 2003, Kilani-Schoch \& Dressler 2005): the French noun system has only fossile synthetic morphology in terms of rare stem-alternating plural formations of the type chev-al 'horse', Pl. chev-aux [Ja'vo], whereas, e.g., English has one productive rule of plural formation plus several marginal and unproductive alternatives (see below) and is thus less isolating than French. In contrast, the French verb system is richer and more complex than the English one (see section 6.).

It holds for an inflecting-fusional language that the richer and more complex the inflection system is, the greater is the hierarchical depth and complexity of a macroclass. Moreover stronger inflecting-fusional languages tend to have more macroclasses and a greater number of productive microclasses. Thus Classical Latin (cf. Dressler 2002) has 4 macroclasses and 6 completely and 5 partially productive microclasses in noun inflection, three macroclasses and 1 totally and 3 partially productive microclasses in verb inflection. Russian verb inflection (Dressler \& Gagarina 1999) has 3 macroclasses and 3 totally and 1 partially productive microclasses. 


\section{Lithuanian Verb Inflection}

The strongest inflecting-fusional language among contemporary Indo-European languages is Lithuanian with 3 macroclasses and 3 totally productive microclasses in verb inflection (out of 44 microclasses), see trees $2 \mathrm{a}-\mathrm{e}$ : the forms given are 3. Prs., 3. Pret. (number is never differentiated for this person), Inf., 1. Sg. Pres. "A" refers to the accented vowel or diphthong of these four inflectional forms.

The proliferation of microclasses is partially due to morphoprosody, i.e. to morphological distinctions expressed by quantity and pitch contour distinctions of stressed vowels.

\section{Russian Verb Inflection}

Russian has three macroclasses. While macroclasses I and II are the biggest classes and contain the majority of microclasses and (monoradical) mini-microclasses, macroclass III consists of only 8 microclasses (cf. trees $3 \mathrm{a}-\mathrm{c}$ ). The four fully productive microclasses are distributed within the two 'main' macroclasses (microclasses 1, 7, 17, 39 - shaded in the tree structure). Despite the long history of establishing verb classes in Russian, the productive classes in descriptive grammars of Russian (e.g. Belošapkova 1997; Lekant 1982; Miloslavskij 1981) are still numbered arbitrarily after Karcevskij (1927). The number of unproductive groups of verbs, corresponding to microclasses, vary in number from seven (Karcevskij 1927), five (Isačenko 1960), seventeen (Vinogradov 1938/1972), up to twenty (Švedova 1980). Bricyn \& Kononenko (1983) claim that "the number of unproductive classes is low and is constantly diminishing". The present classification (cf. Dressler \& Gagarina 1999), however, shows that this is not the case: we assume 50 microclasses. Macroclass I and II differ in that they establish the correlation between the two stems of verbs, the open 'vowel' stem and the close 'consonant' stem, on the basis of morphotactic addition vs. deletion. Thus, the correlation of the verb stems in macroclass I is Vowel vs. Vowel+Consonant, where the appended consonant is predominantly $-j$ and only marginally $-n$ or $-v$. Macroclass II is characterized by the deletion of the last vowel in conjunction with various morphonological processes.

\section{Latin Verb Inflection}

Morphological richness is established by its productive patterns, complexity also by its unproductive patterns (cf. Dressler 1999). The complex unproductive part of an inflection system of the inflecting-fusional type is characterised by the presence of special minor types of unproductive microclasses, so-called mini-microclasses, as can be illustrated with macroclasses I and II of the three macroclasses of Latin verb inflection (tree 4). 
a) mini-microclasses which consist just of 2 or 3 members: e.g. caveo 'to pay attention', faveo 'to favour', Perf. c/favi, Perf.Pass.Part. c/fautum vs. foveo 'to warm', moveo 'to move', voveo 'to dedicate', Perf. $\mathrm{f} / \mathrm{m} /$ vovi, $\mathrm{f} / \mathrm{m} /$ votum.

b) monoradical mini-microclasses, such as Lat. video, in-video, pro-video, etc. These verb paradigms cannot be classified as one isolated paradigm, because the meanings of the prefixed verbs in-video 'to envy' and pro-video 'to provide' are morphosemantically too opaque for making them compositional derivatives of the simplex video 'to see'.

c) Some monoradical mini-microclasses may be bound-root microclasses at the same time, e.g. con-sto, con-stare, con-stiti 'to be certain' plus in-stare 'to insist', ob-stare 'to withstand', prae-stare 'to afford', etc., vs. the isolated paradigm stare, steti 'to stand'. Here morphosemantic opacity is also iconically reflected in more morphotactic opacity in perfect formation.

\section{French Verb System}

The French verb system presents a typologically interesting case because it equally approaches the inflecting-fusional and isolating type (cf. Dressler \& Kilani-Schoch 2003, Dressler et al. 2003, Kilani-Schoch \& Dressler 2005). It has only two macroclasses, such as the weakly inflecting-fusional languages Italian, Spanish, German, Dutch, English. It has less microclasses than Italian, but more than the other languages just cited. It has only two macroclasses, i.e. verbs in Inf. -er (e.g. parl-er 'speak' vs. Pres.Sg. [paRl]) on the one hand vs. verbs in $-i(-) r$ (e.g. finir 'finish', sortir 'go out' vs. [fi'ni, soR], -re (e.g. perdre 'loose' vs. [per]) and -oi(-)r (e.g. croire 'believe', pleuvoir 'rain' vs. [kRwa, plø]) on the other hand. The above-mentioned weakly inflecting-fusional languages have two macroclasses as well, in contradistinction to strongly inflecting languages, which have more macroclasses. However French has less microclasses than Italian, but more than the other languages cited. Thus at least its verb trees are deeper and more complex than those of German (cf. trees 5a-c vs. tree 1).

Surprisingly French has, on the one hand, 3 productive microclasses (types parl-er 'speak', sem-er 'sow', céd-er 'yield'), whereas the Germanic languages cited have just 1 (default of weak verbs) and the other Romance languages cited just 1 totally and 1 very weakly productive microclass (as in Spanish, s. Aguirre \& Dressler, this volume, for Romanian see Sánchez Miret, this volume). However these 3 productive microclasses of French are phonologically strictly complementary in their root alternations, i.e. in the microclass of parl-er there are no verbs whose stem vowel consists of either a closed or open <e> or schwa followed by a root-final consonant. If a verb has such a stem vowel, it falls automatically either in the second or in the third microclass (sem-er or céd-er). Such a phonological complementarity does not exist in the productive microclasses of the stronger inflecting-fusional verb systems of Lithuanian and 
Russian (see above), Polish (7 productive microclasses), Croatian and Slovene (each 4 productive microclasses). Such phonological complementarity (a diachronic consequence of relatively recent morphologization and thus inflection class split) means greater homogeneity and thus less morphological diversity than is the case with the productive microclasses of the stronger inflecting-fusional languages.

On the other hand, the great majority of the microclasses of the completely unproductive French macroclass II are mini-microclasses or other minor unproductive microclasses (as illustrated with Latin), i.e. 21 of 29 microclasses. Such a relationship does not occur in stronger inflecting-fusional inflection systems, but recalls very weakly inflecting English which abounds in mini-microclasses, such as foot-feet, goose-geese and mouse-mice, louse - lice.

\section{Agglutinating Type}

A strongly agglutinating language has nearly no inflection class differentiation at all (cf. Pöchtrager et al. 1998): thus Turkish noun inflection has just two (productive) microclasses, the default microclass and the phonologically defined microclass of köpek 'dog', Acc. köpe-i. Turkish verb inflection has 3 microclasses: the default one, the verbs with aorist -ir-instead of -er-, and the mini-microclass of ye-mek 'to say', de-mek 'to eat'.

Hungarian noun inflection is less strongly agglutinating (with a few properties of the inflecting-fusional type). It has two macroclasses with 3 productive and 13 unproductive microclasses. Its tree structure is very shallow and of little complexity, quite different from the structures of inflecting-fusional languages, see trees 7a-b (Nom. Sg., Acc. Sg., Poss. Sg.).

Currently a class shift is taking place from the unproductive microclass 13 to the productive microclass 1 .

Finnish noun inflection (where there are still more properties of the inflecting-fusional type than in Hungarian) has two macroclasses and six productive and twelve unproductive microclasses. The tree structure is still shallow, but less so than Hungarian, and has a little more complexity than Hungarian, see trees 7a-b.

In Finnish, the number of productive microclasses is high, but notice the phonological complementarity similar to what we pointed out above for French. The microclass differentiation corresponds in many cases to differing stem-final vowels (in contrast to French, where complementarity is based on the stem vowel) and to only slightly diverging morphonological alternations. The unproductive classes are in most cases associated with a particular derivational suffix, e.g. microclass 12 contains only nouns with the derivational suffix $-(u) u s /-(y) y s$ '-ness, -ity'.

Another characterising property of agglutinating languages, viz. the superstability of their markers, is not evident from the diagrams, but holds for both 
Hungarian and Finnish (as well as evidently for Turkish). Thus, the paradigms resemble each other very much; in Finnish, the little allomorphy which exists in the inflectional suffixes can be straightforwardly predicted from the stem shape. As mentioned in the case of French, nominal and verbal inflection can differ in their complexity. No such imbalance is to be found in Finnish, where the system of noun inflection has an only slightly more complex hierarchy than verbal inflection (cf. Pöchtrager et al. 1998).

\section{Typological Conclusions}

The typological properties identified above can be derived from more basic properties of the respective ideal language type (in the sense of Skalička 1978; 2002 and Dressler 1985): the great preference for biuniqueness of the agglutinating type excludes, in its ideal construct, the differentiation of inflection classes, whereas the great ambiguity inherent in the ideal inflecting-fusional type favours it. The absolute morphosemantic transparency of the agglutinating type not only excludes parasitic inflection (as in the French conditional, which only looks like an imperfect of the future, cf. Kilani-Schoch \& Dressler, in print), but also the often opaque category of gender in noun inflection, whose presence in the inflecting-fusional type leads to proliferation of inflection classes in noun morphology (the presence of gender in the rather agglutinating Dravidian languages complicates noun inflection as well). The great preference for morphotactic transparency in agglutinating languages is also an obstacle to the proliferation of inflection classes, thus the differentiation of inflection classes in Hungarian and Finnish is due to opacity as well as to partial lack of biuniqueness. In the inflecting-fusional type, morphotactic opacity (especially in its strong form of fusion) increases class differentiation and makes tree structures deeper and more complex. Finally, in the ideal agglutinating type all morphological patterns are productive, whereas the ideal inflecting-fusional type has more productive than unproductive inflectional categories and rules, but due to opacity and ambiguity many more unproductive than productive microclasses, which makes tree structures very complex.

Also the ideal isolating type excludes inflection class differentiation. Thus in the diachronic development, e.g., of Latin to French and of Old to Modern English, certain innovations may superficially resemble developments towards an agglutinating language, but profounder analysis (as in Dressler \& KilaniSchoch 2004) shows that the apparent similarity with agglutinating languages is a secondary consequence of greater iconicity shared by weakly inflecting-fusional with agglutinating languages, as opposed to stronger inflecting languages. But a very close approximation to the ideal isolating type, as in French noun inflection, reduces iconicity again. 
Although inflection class systems have not yet been investigated in detail for languages approaching the ideal introflecting and incorporating types, the criteria introduced in this contribution and derived from higher-order properties of the model of Natural Morphology have shown its potential for typological differentiation for the other morphological language types.

\section{Addresses of the authors}

Wolfgang U. Dressler - Lina Pestal - Markus Pöchtrager

Institut für Sprachwissenschaft der Universität Wien

Berggasse 11

1090 Wien

Austria

wolfgang.dressler@univie.ac.at, lina.pestal@univie.ac.at, markus.poechtrager@univie.ac.at

Marianne Kilani-Schoch

Université de Lausanne, Faculté des lettres

Ecole de français langue étrangère (FLE)

Quartier UNIL-Dorigny, Bâtiment Humense 2100,

1015 Lausanne

Switzerland

Marianne.KilaniSchoch@unil.ch

Natalia Gagarina

Zentrum für Allgemeine Sprachwissenschaft,

Typologie und Universalienforschung (ZAS)

Jägerstraße 10 / 11

10117 Berlin

Germany

gagarina@zas.gwz-berlin.de

\section{References}

Aguirre, Carmen \& Wolfgang U. Dressler 2006. "On Spanish verb inflection.” This volume.

Belošapkova, Vera A. 1997. Sovremennyj russkij jazyk. Moskva: Azbukovnik.

Bittner, Andreas. 1996. Starke 'schwache' Verben - schwache 'starke' Verben: Deutsche Verbflexion und Natürlichkeit. Tübingen: Stauffenburg.

Bricyn, Mikhail A. \& Viktor I. Kononenko. 1983. Sovremennyj russkij jazyk. Kiev: Višča Škola.

Corbett, Greville \& Norman Fraser. 1993. "Network morphology: a DATR account of Russian inflectional morphology." Journal of Linguistics 29. 113-142.

Dressler, Wolfgang U. 1985. "Typological aspects of Natural Morphology." Acta Linguistica Hungarica 35, 51-70.

Dressler, Wolfgang U. 1999. "Ricchezza e complessità morfologica.” In: Fonologia e Morfologia dell'Italiano e dei Dialetti d'Italia. Atti del 21. congresso SLI. Roma: Bulzoni, 587-597.

Dressler, Wolfgang U. 2002. "Latin inflection classes." In: A.M. Bolkestein et al. eds. Theory and Description in Latin Linguistics. Amsterdam: Gieben, 91-110. 
Dressler, Wolfgang U. 2003. "A sketch of dynamic morphology of German verb inflection.” In: H.G. Jacobsen et al. eds. Take Danish - for instance, Fs. H. Basbøll. Odense: University Press of Southern Denmark, 29-39.

Dressler, Wolfgang U. \& Katarzyna Dziubalska-Kołaczyk. 1997. "Polish inflection classes within Natural Morphology.” Bulletin de la Société Polonaise de Linguistique 53, 95-119.

Dressler, Wolfgang U., Katarzyna Dziubalska-Kołaczyk \& Antigone Katičić. 1996. "A contrastive analysis of verbal inflection classes in Polish and Croatian." Suvremena lingvistika $22,41-42,127-138$.

Dressler, W.U. \& Natalia Gagarina. 1999. "Basic questions in establishing the verb classes in contemporary Russian.” In: L. Fleishman et al. eds. Essays in Poetics, Literary History and Linguistics, Fs. V.V. Ivanov. Moskva: OGI, 754-760.

Dressler, W.U. \& Marianne Kilani-Schoch. 2003. "Hierarchy and the Classification of French Verbs.” In: M.R. Wise et al. eds. Language and Life: Essays in Memory of K.L. Pike. Dallas: SIL, 551-567.

Dressler, W.U. \& Marianne Kilani-Schoch. 2004. "Iconicité dans la flexion verbale du français." In: G. Fenk-Oczlon ed. Sprache und Natürlichkeit, Gedenkschrift für Willi Mayerthaler. Tübingen: Narr, 57-74.

Dressler, W.U., Marianne Kilani-Schoch, Rossella Spina \& Anna M. Thornton. 2003. "Le classi di coniugazione in italiano e francese.” In: M. Giacomo-Marcellesi \& A. Rocchetti eds. Il Verbo Italiano. Roma: Bulzoni, 397-416.

Dressler, Wolfgang \& Jasna Makovec-Černe. 1995. Die ersten Stufen des Erwerbs der slowenischen Flexion: Eine Fallstudie. Travaux du Cercle Linguistique de Prague, N.S. 1, 249-260.

Dressler, Wolfgang U. \& Anna M. Thornton 1996. "Italian nominal inflection”. Wiener linguistische Gazette 57-59, 1-26.

Isačenko, Aleksandr V. 1960. Grammatičeskij stroj russkogo jazyka v sopostavlenii so slovackim. Bratislava: Slovackaja AN.

Karcevskij, Serge 1927. Système du verbe russe. Essai de linguistique synchronique. Prague.

Kilani-Schoch, Marianne \& Wolfgang U. Dressler. 2005. Morphologie naturelle et flexion du verbe français. Tübingen: Narr.

Kilani-Schoch, Marianne \& Wolfgang U. Dressler. in print. "Compositionnalité et iconicité dans la flexion du verbe français. Une approche de morphologie naturelle." Verbum.

Lekant, Pawel A. 1982. Sovremennyj russkij literaturnyj jazyk. Moskva: Vysšaja škola.

Manova, Stela \& W.U.Dressler 2001. "Gender and declensional class in Bulgarian." Wiener linguistische Gazette 67-69, 45-81.

Miloslavskij, Igor' 1981. Morfologičeskije kategorii sovremennogo russkogo jazyka. Moskva: Prosveščenije.

Pöchtrager, Markus, Csanád Bodó, Wolfgang U. Dressler \& Teresa Schweiger. 1998. “On some inflectional properties of the agglutinating type, illustrated from Finnish, Hungarian and Turkish inflection." Wiener linguistische Gazette 62-63, 57-92.

Sánchez Miret, Fernando. 2006. "Productivity of the weak verbs in Romanian." This volume.

Skalička, Vladimír. 1978. Typologische Studien. Braunschweig: Vieweg.

Skalička, Vladimír. 2002. Die Typologie des Ungarischen. Travaux du Cercle Linguistique de Prague 4, 101-108.

Švedova, N. J. (ed.) 1980. Russkaja grammatika ... Moskva: Nauka, AN SSSR.

Vinogradov, Viktor V. 1938/1972. Sovremennyj russkij jazyk (grammatičeskoe učenie o slove). Moskva: Vysšaja škola.

Wurzel, Wolfgang U. 1984. Flexionsmorphologie und Natürlichkeit, Berlin: Akademie-Verlag [Engl. translation: Inflectional Morphology and Naturalness. Dordrecht: Kluwer]. 


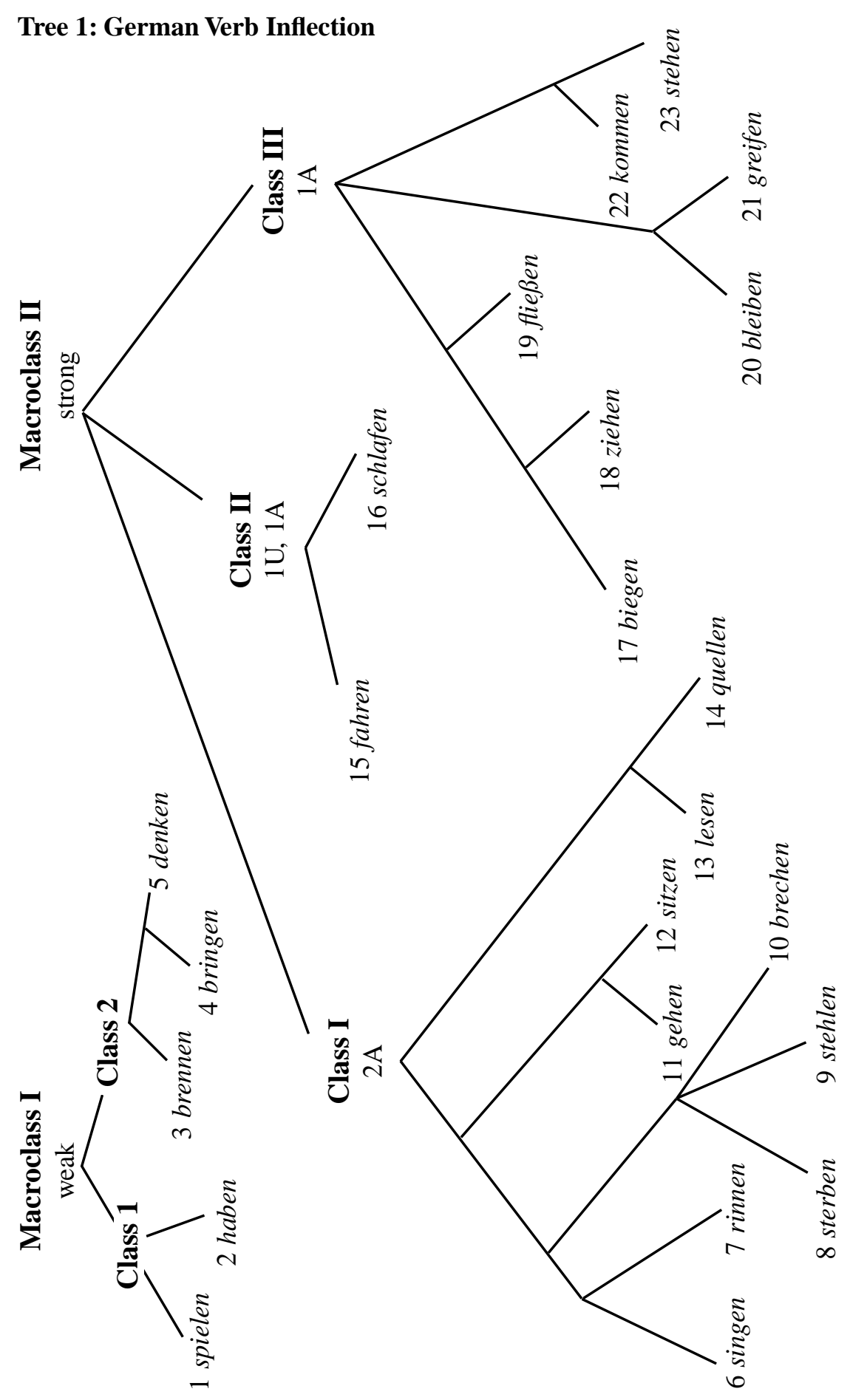


Tree 2a:

Lithuanian

Verb Inflection

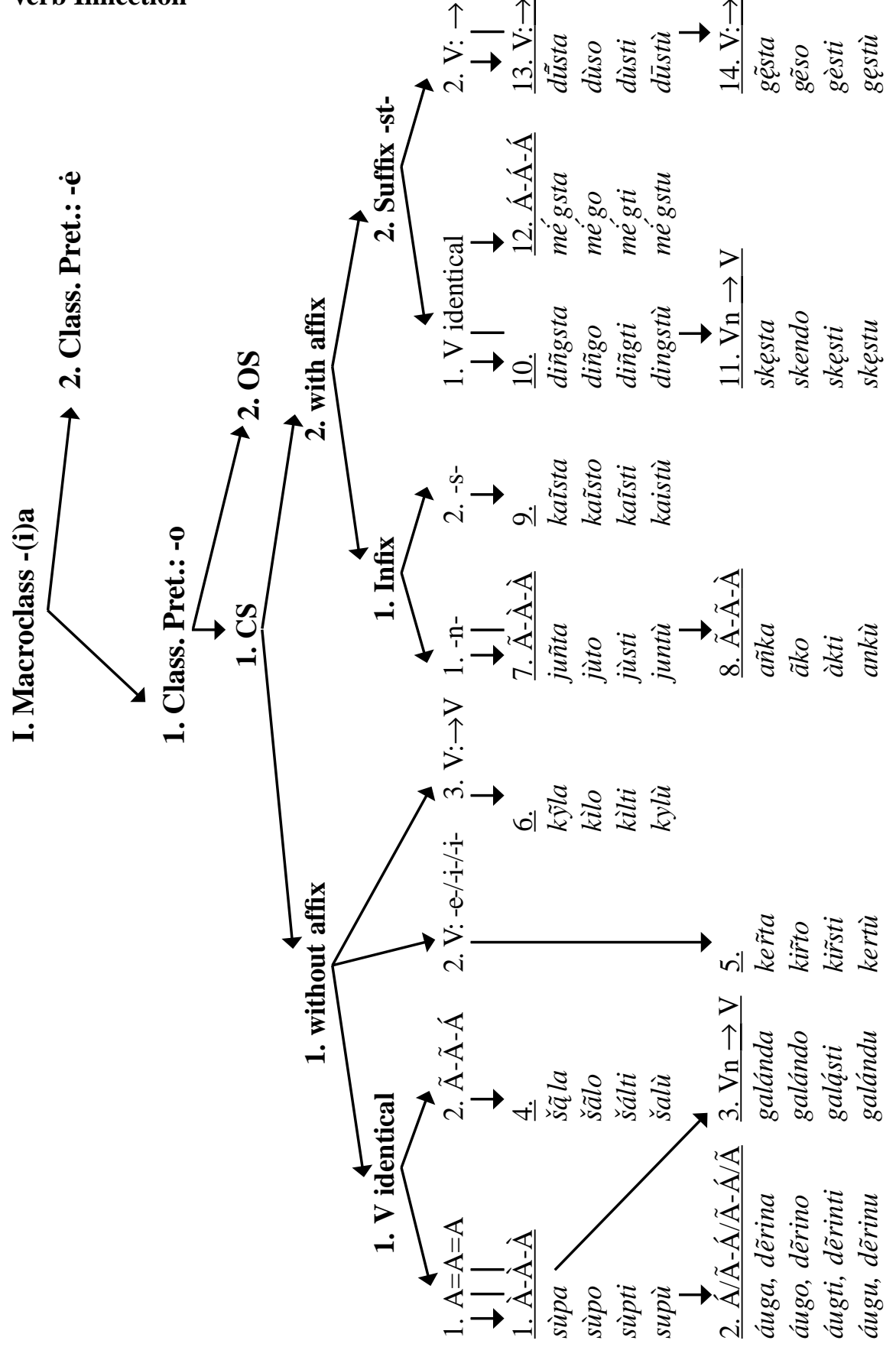


Tree 2b: Lithuanian Verb Inflection

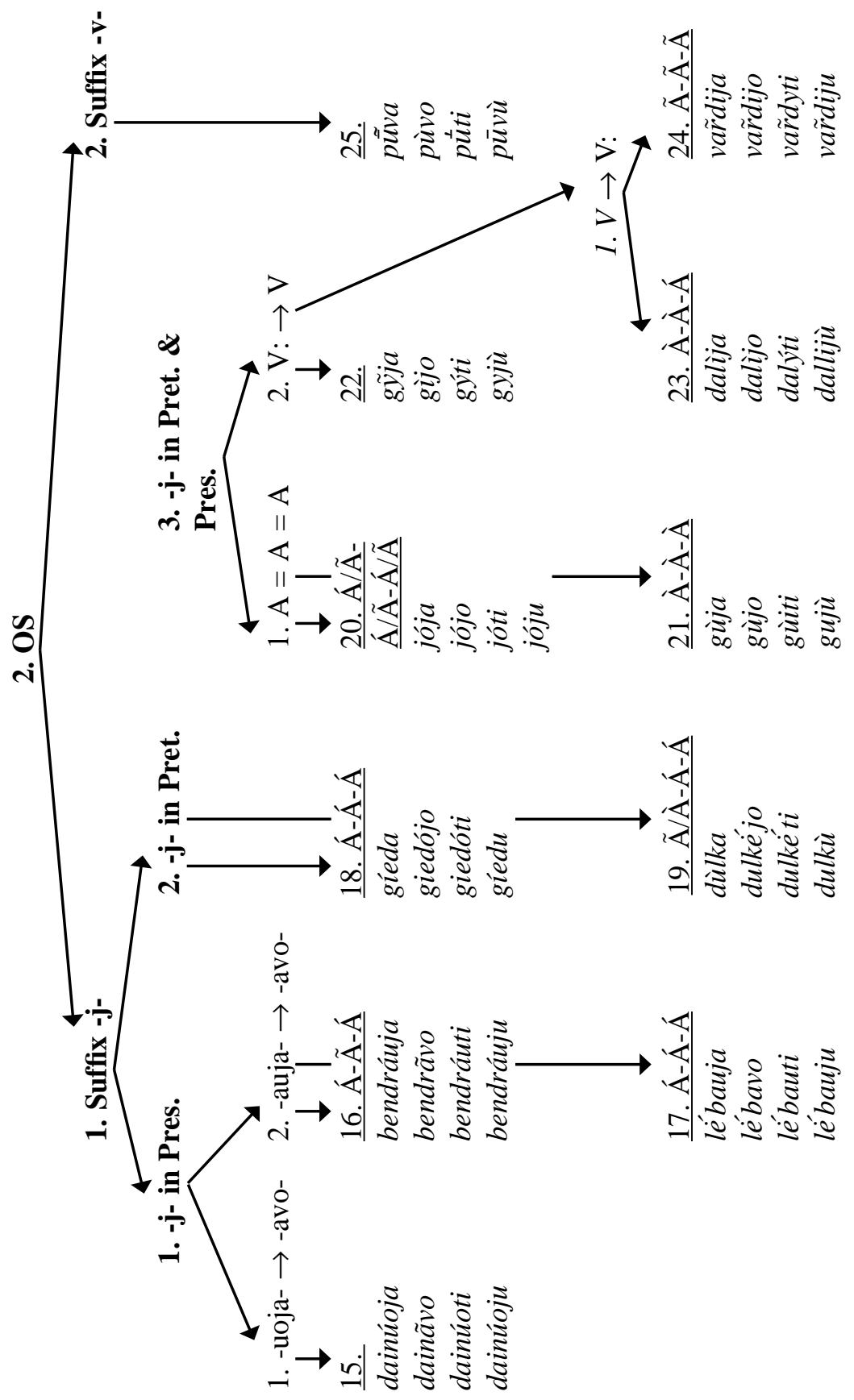


Tree 2c:

Lithuanian

Verb Inflection
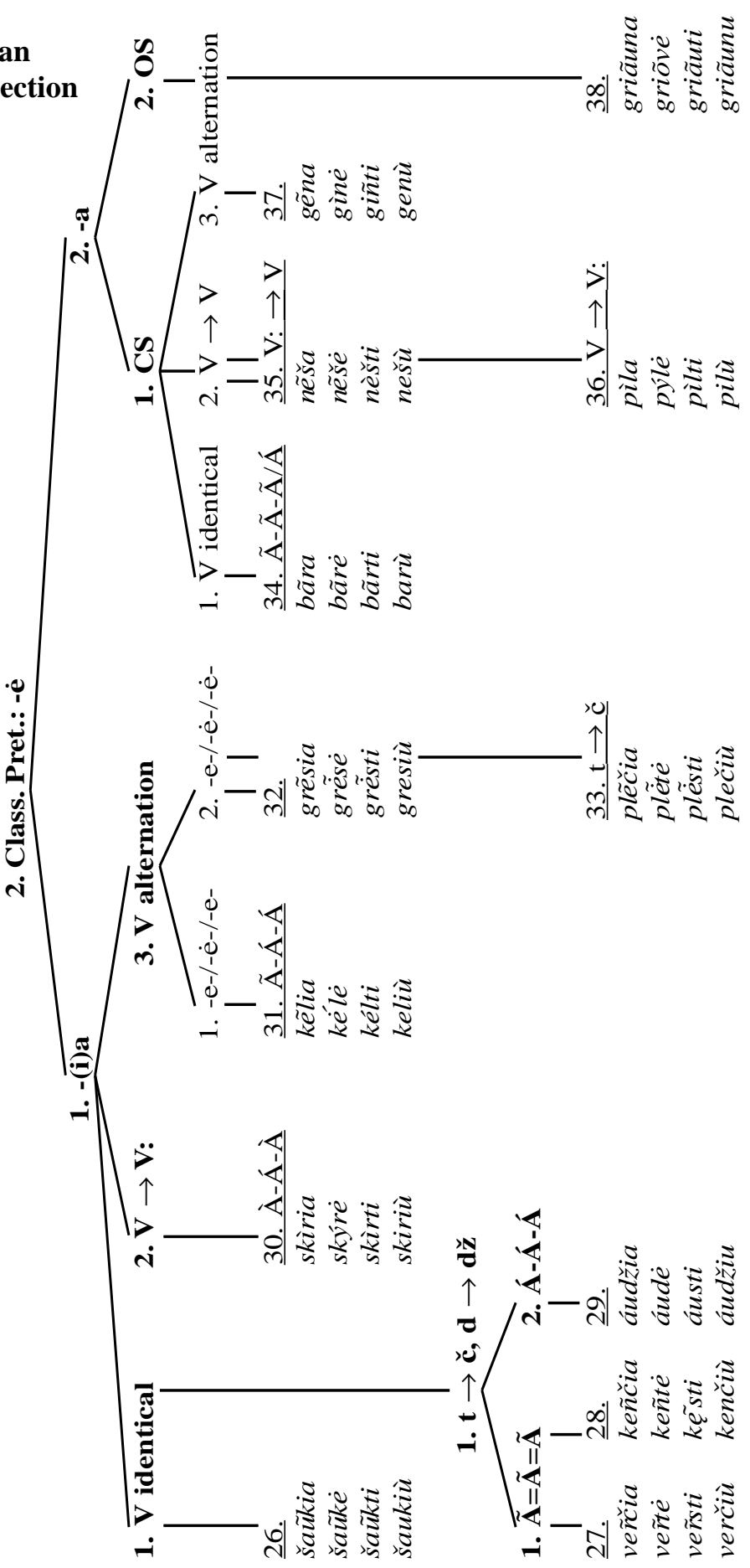
Trees 2d, e: Lithuanian Verb Inflection
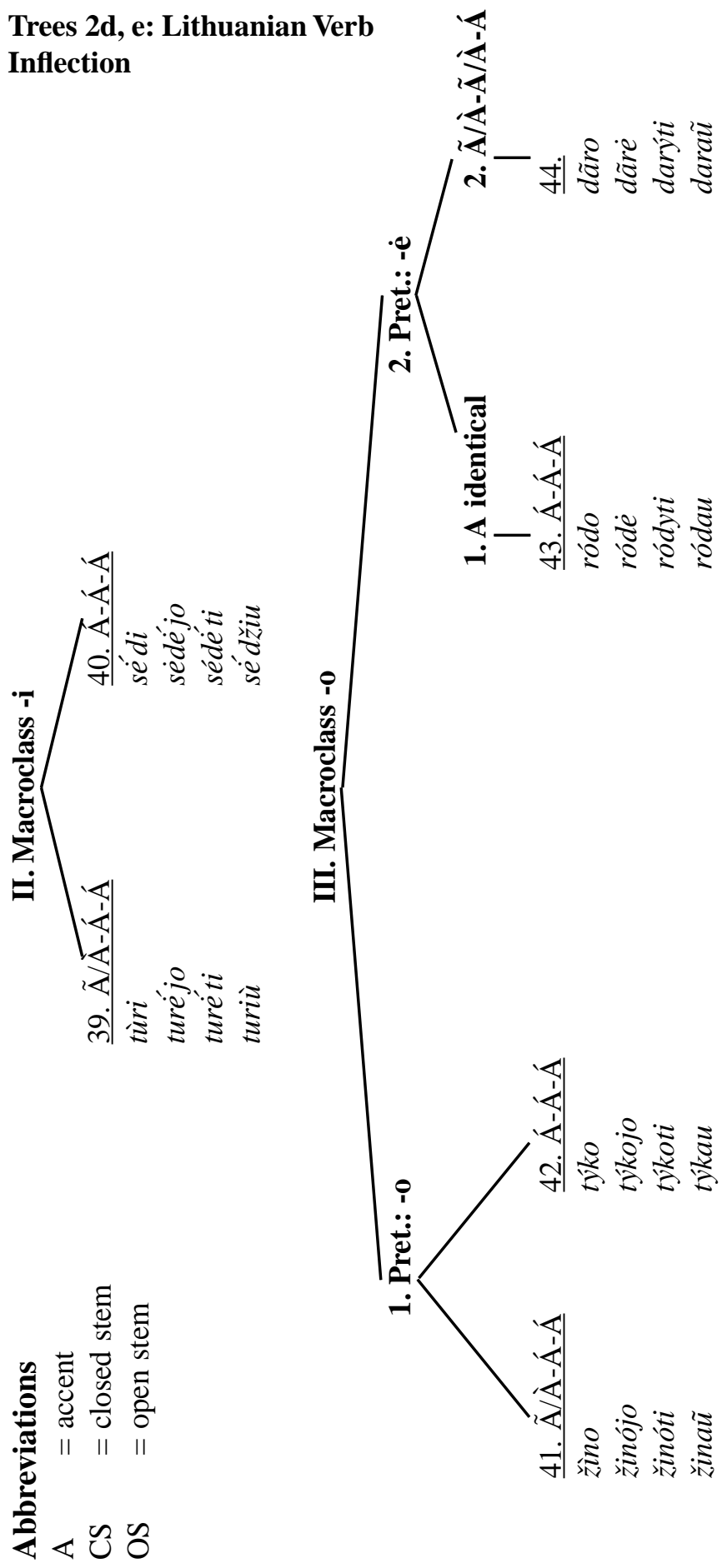
Tree 3a:

RussianVerb Inflection

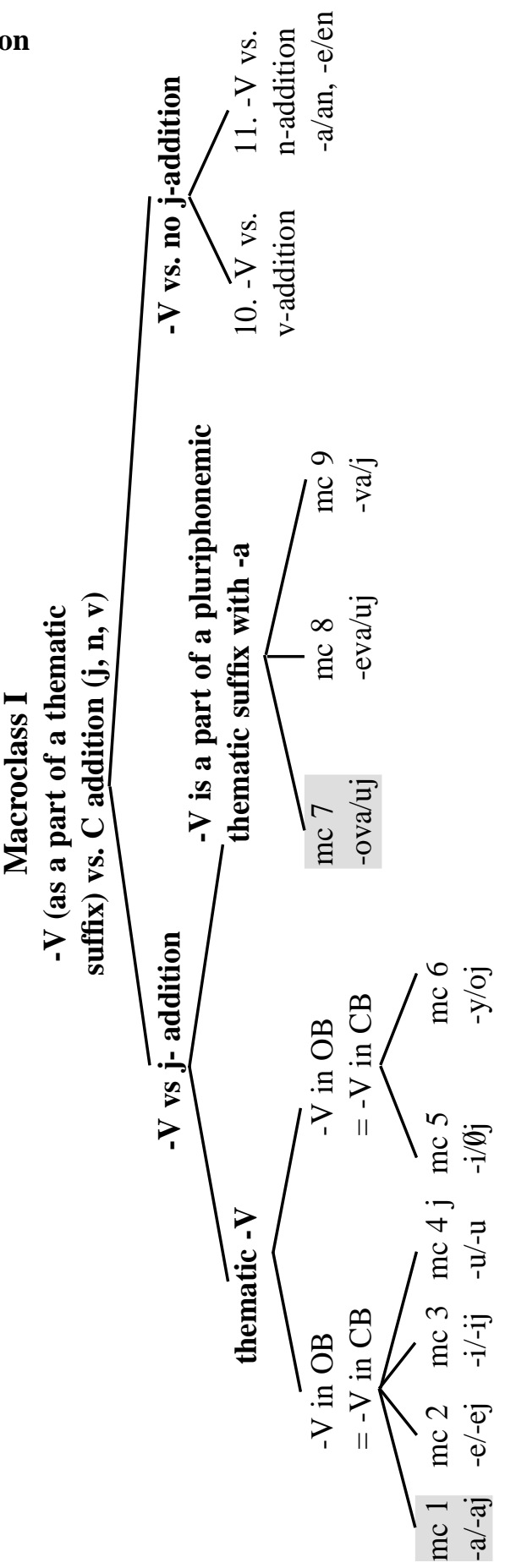




\section{Tree 3b:}

Russian Verb

Inflection

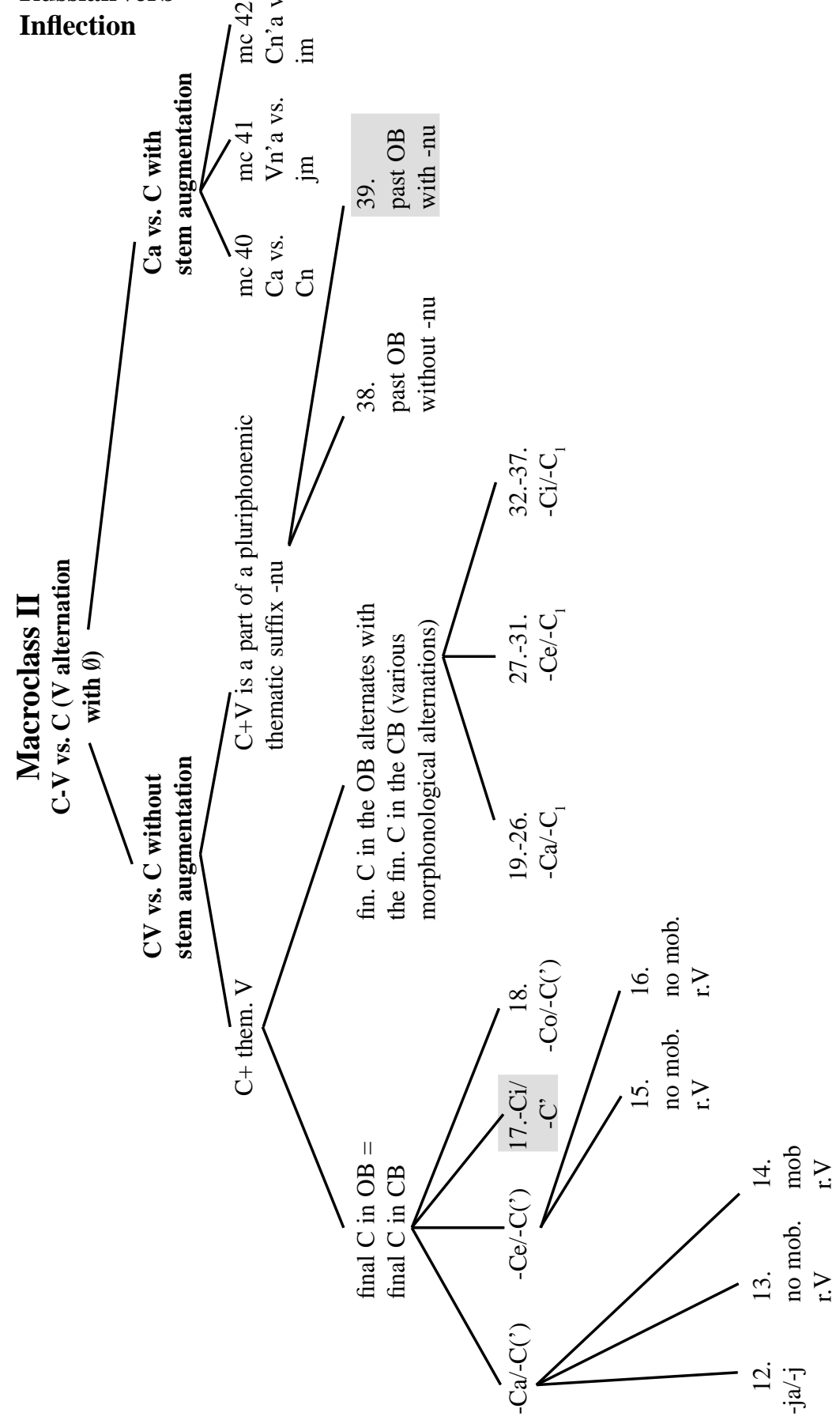




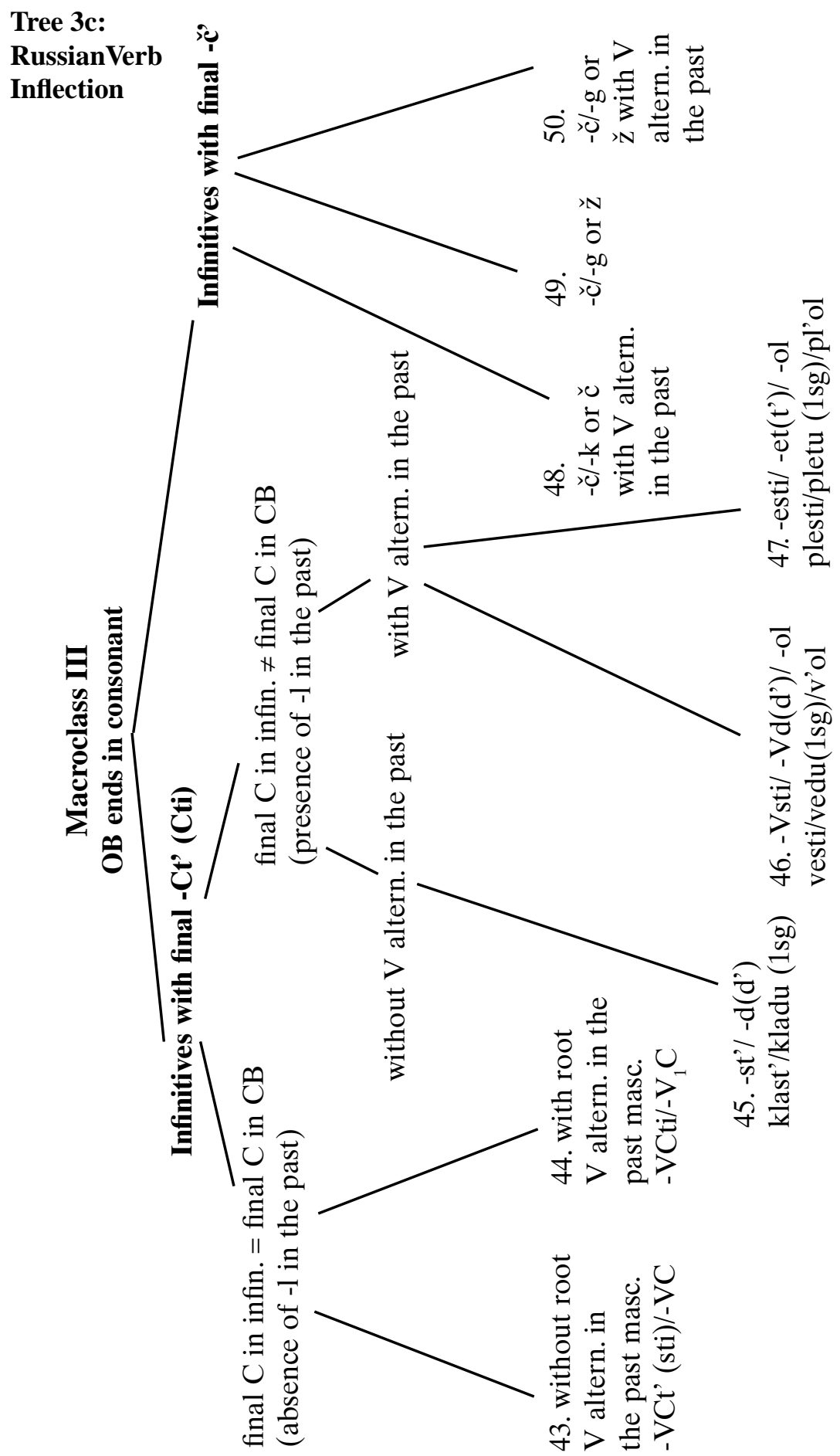


Tree 4: Latin Verb Inflection
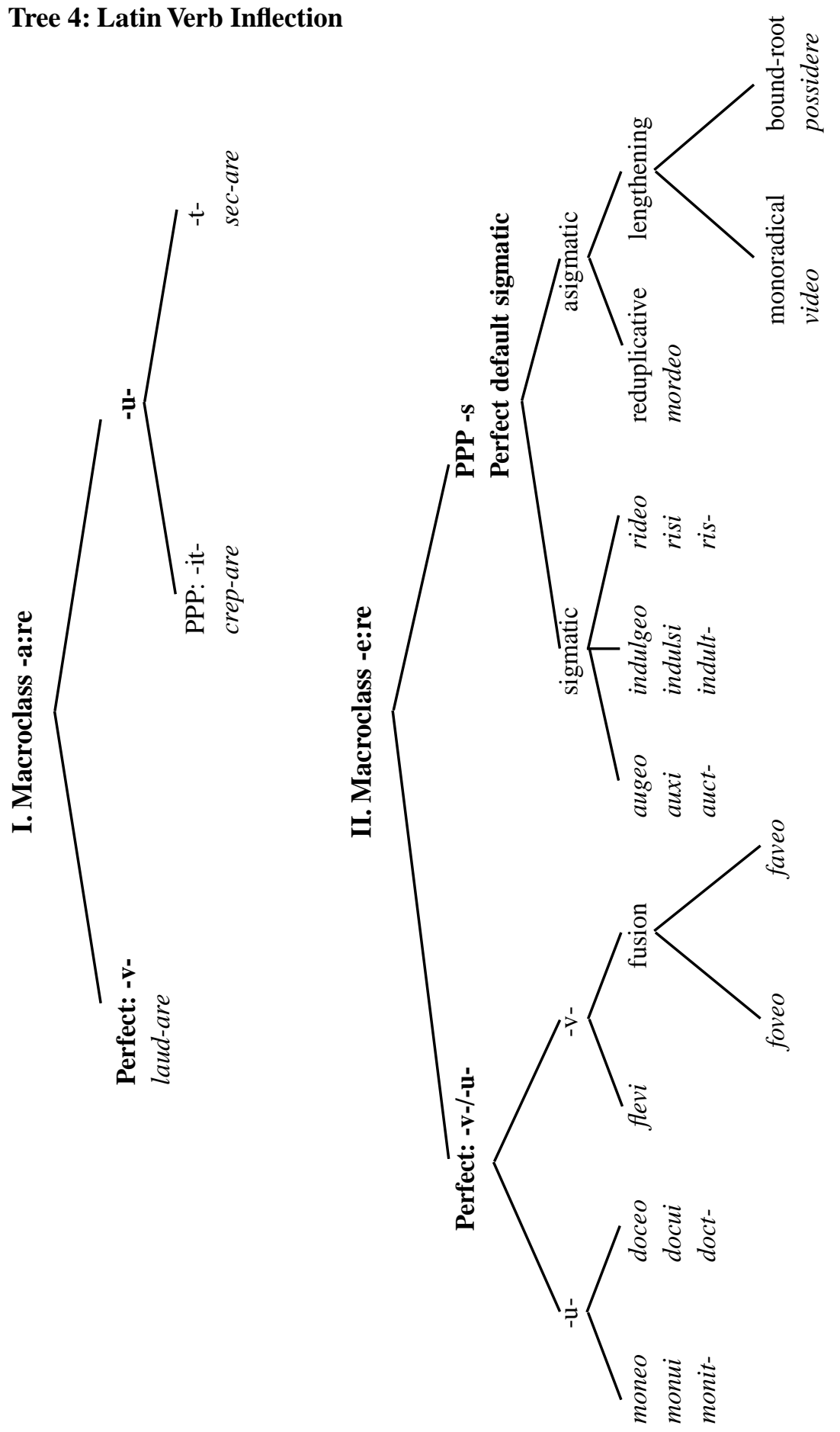


\section{Tree 5a: French Verb Inflection}
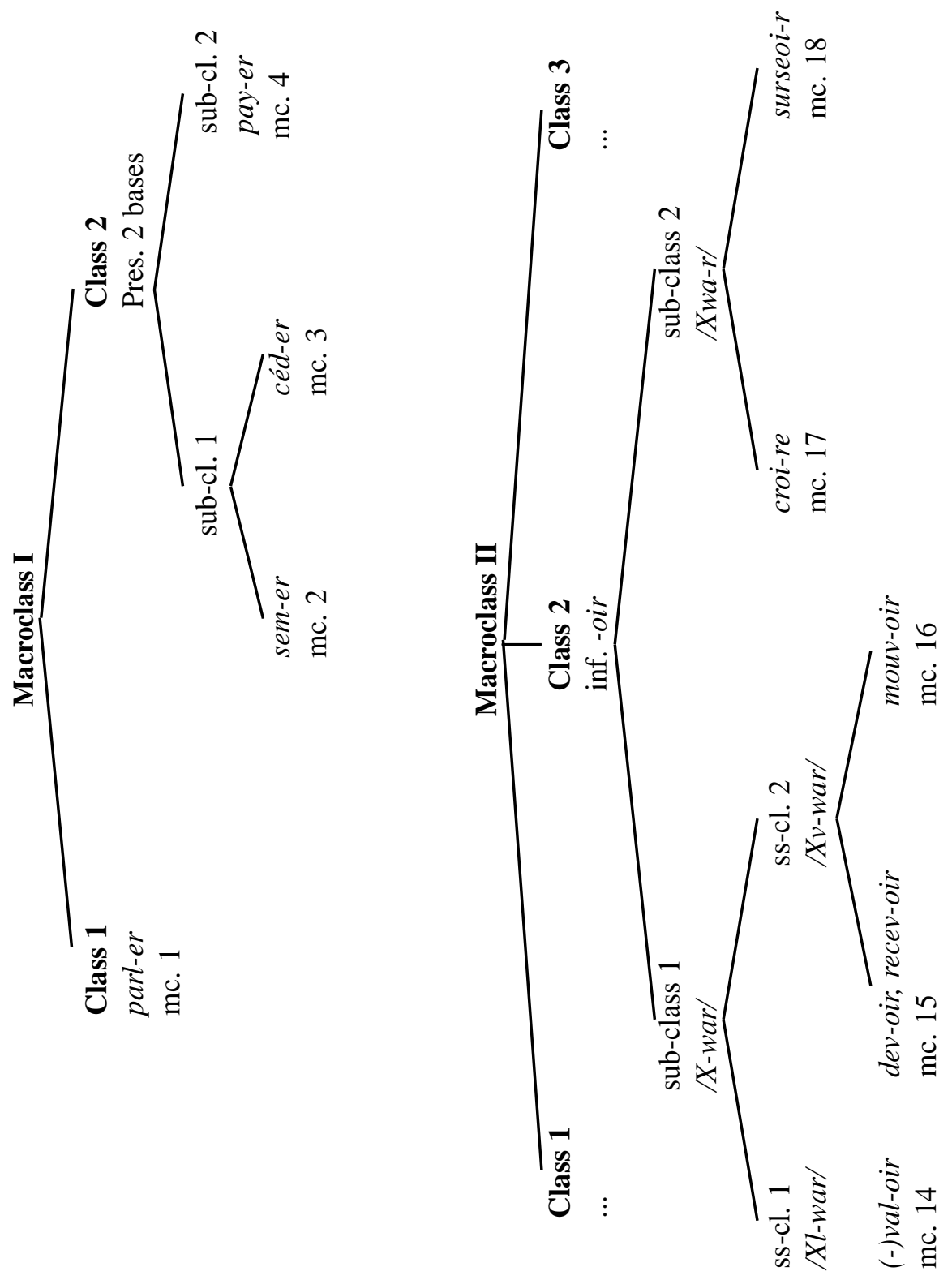


\section{Tree 5b: French Verb Inflection}

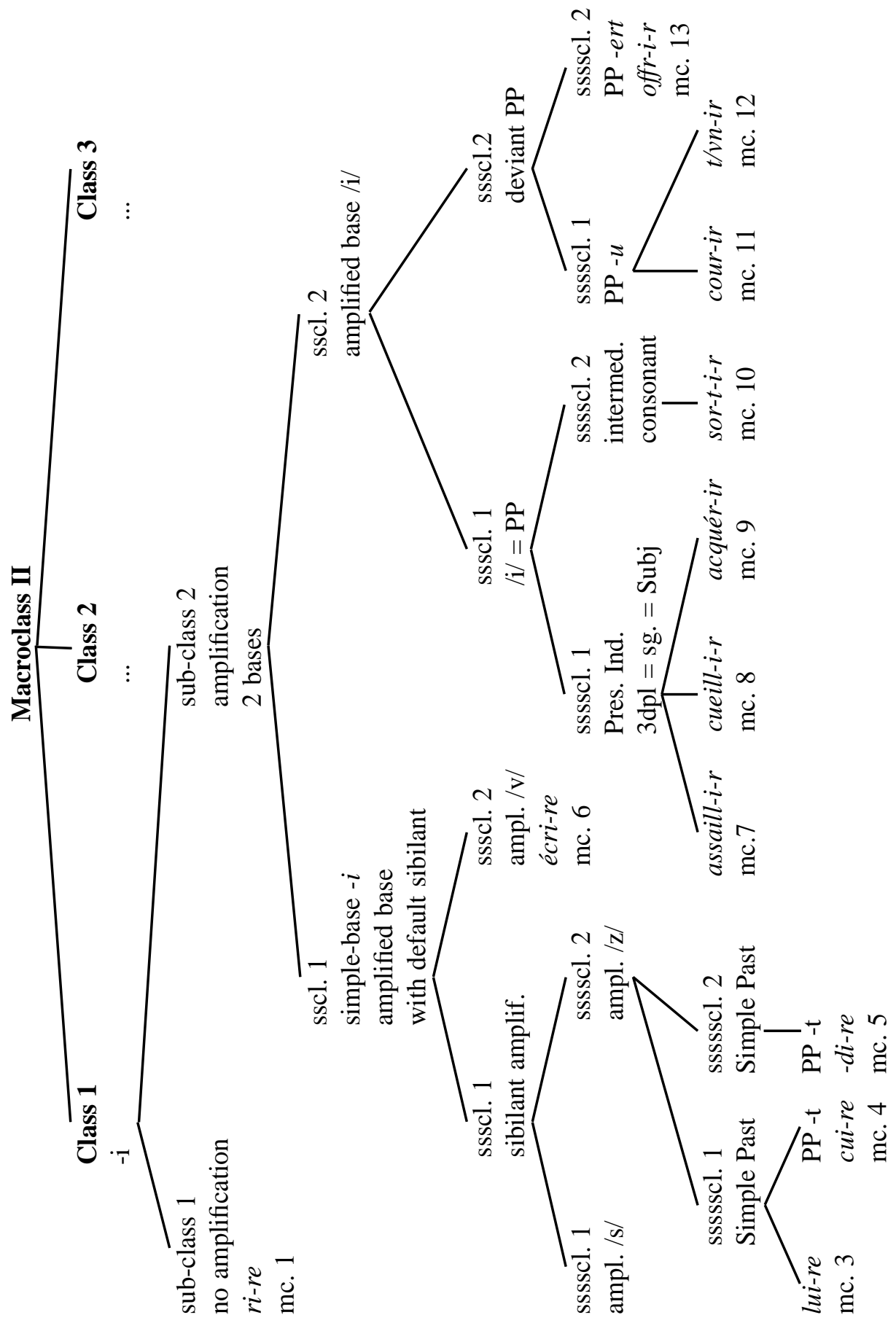


Tree 5c: French Verb Inflection

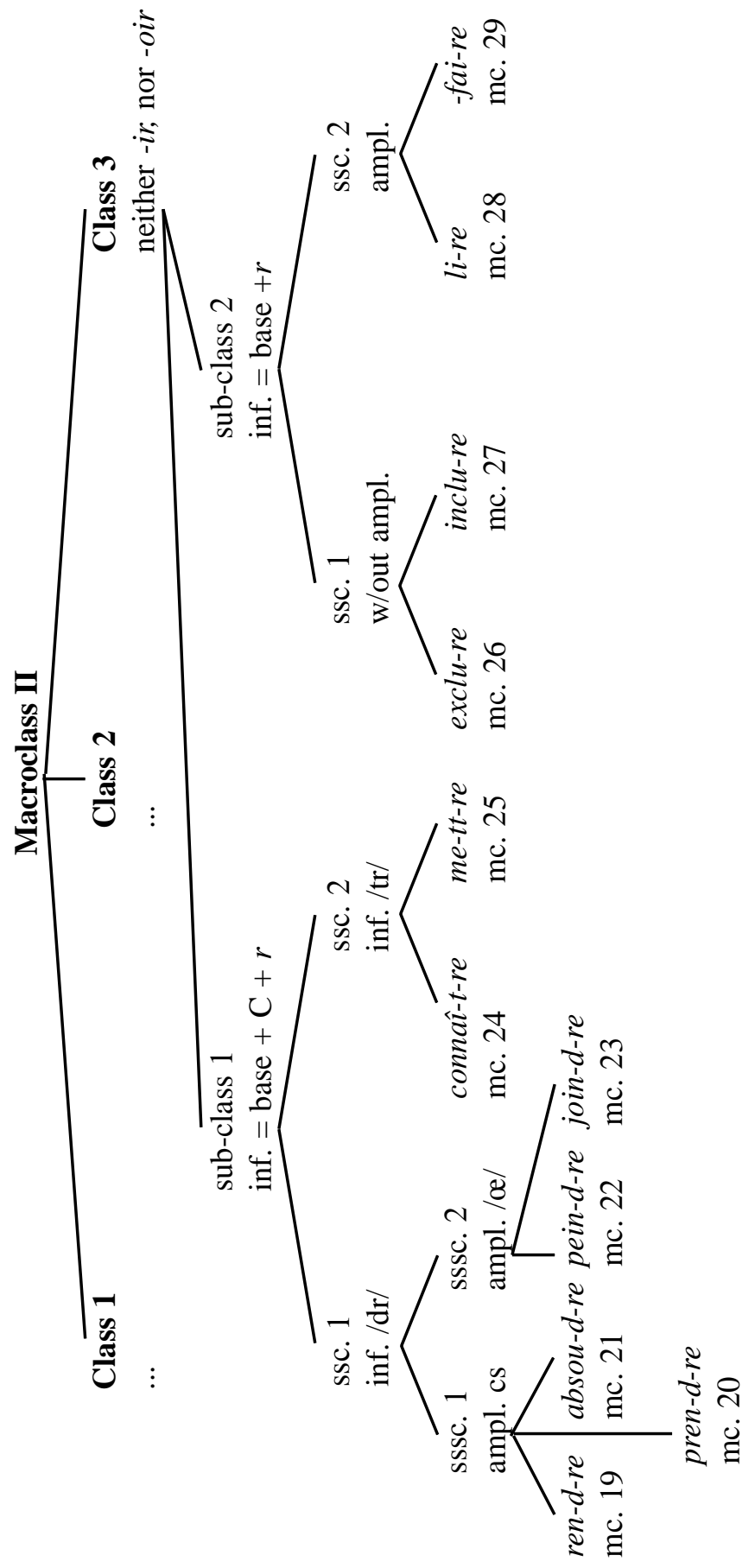


Tree 6a: Hungarian Noun Inflection

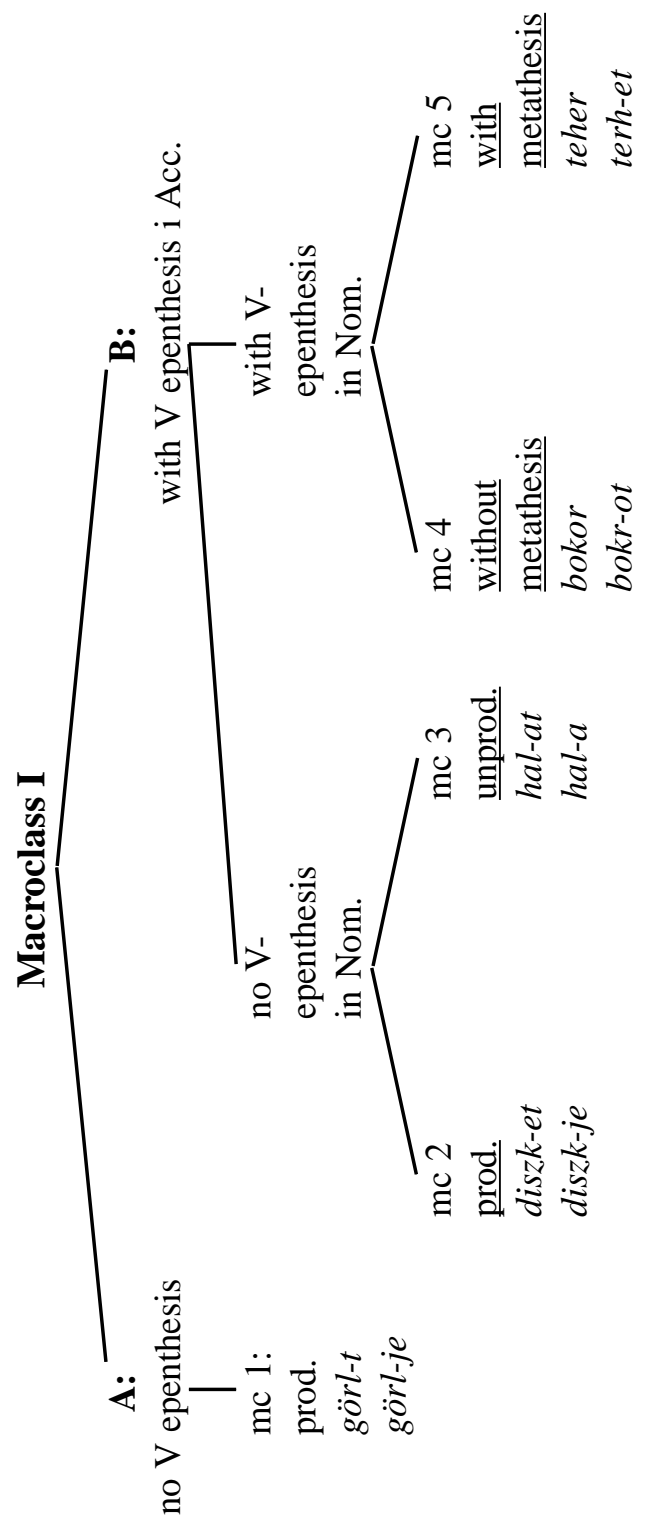


Tree 6b: Hungarian Noun Inflection

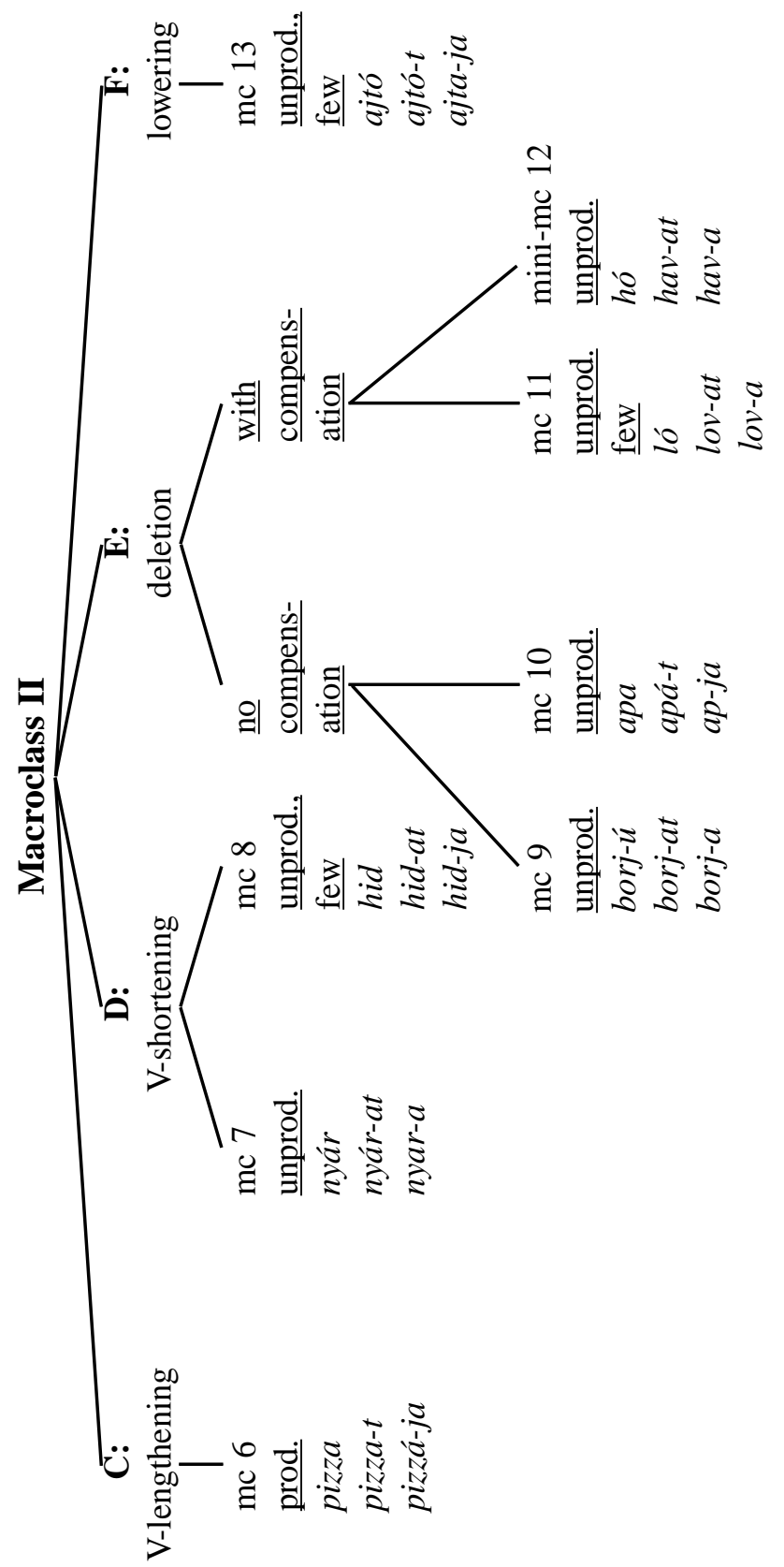


Trees 7a, b:

Finnish Noun $0 \ddot{\bar{Q}}$

Inflection $\quad \frac{\vec{\sigma}}{\pi} \uparrow$

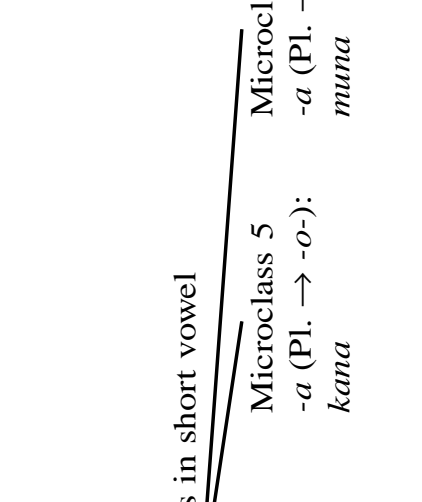

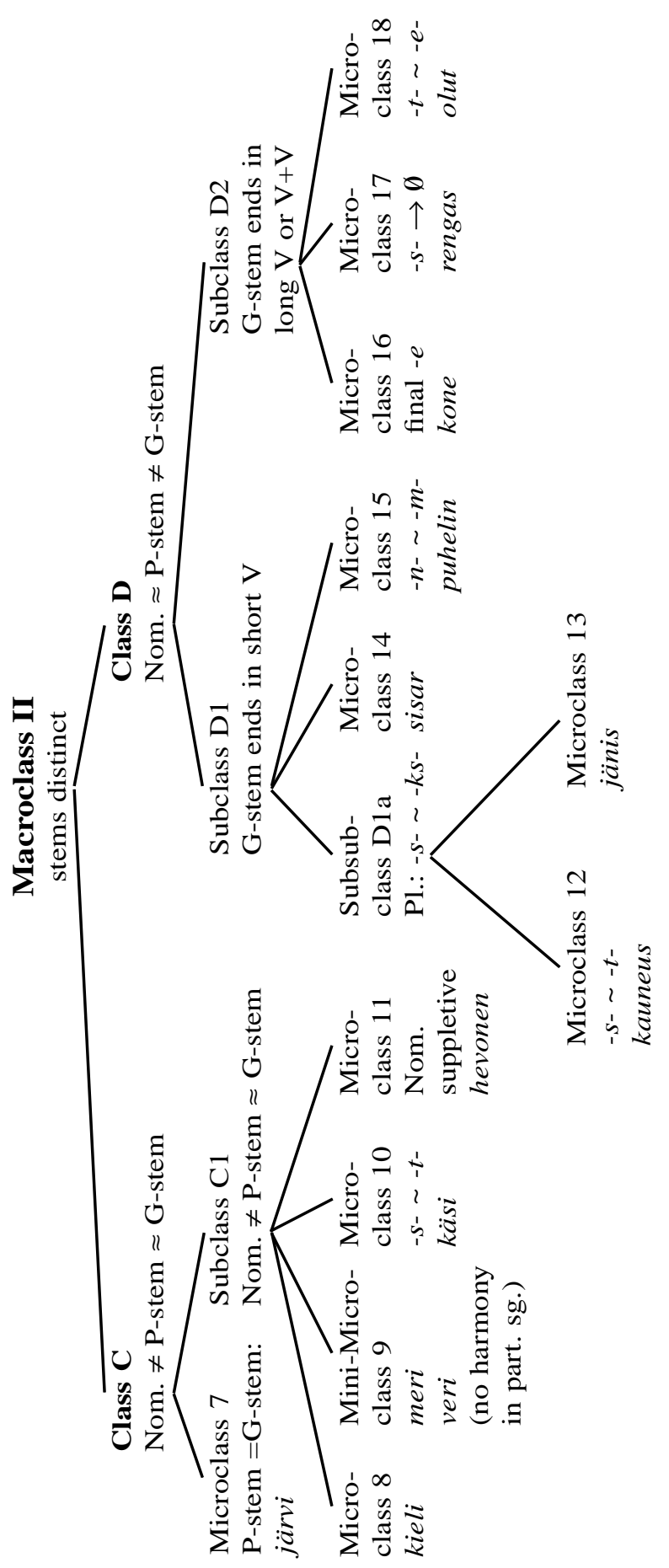

